\title{
STRATEGI KOMUNIKASI INTERPERSONAL GURU DALAM MEMBANGUN KEPERCAYAAN DIRI SISWA KELAS IX UNTUK MENGHADAPI UJIAN AKHIR SEKOLAH BERSTANDAR NASIONAL (USBN) DI MTs NEGERI 10 MAJALENGKA
}

\author{
Arien Nur Rahmanita ${ }^{1}$, Etty Ratnawati ${ }^{2}$ \\ IAIN Syekh Nurjati Cirebon, ${ }^{1,2}$ \\ rahmanitaarien12@gmail.com;ettyratnawati69@gmail.com
}

\begin{abstract}
Abstrak
Penelitian ini dilatarbelakangi Banyak siswa yang mengalami krisis kepercayaan diri saat mengikuti (USBN). Seperti rasa tidak percayadiri, minder, takut, dan cemas yang dialami oleh siswa. Dibutuhkan kecakapan komunikasi yang dilakukan guru agar membangun rasa kepercayaan diri dalam siswa melalui komunikasi interpersonal.Tujuan dari penelitian ini yaitu: 1). Untuk mengetahui kepercayaan diri siswa kelas IX dalam menghadapi USBN, 2).Untuk mengetahui strategi komunikasi interpersonal guru untuk membangun kepercayaan diri siswa, 3). Untuk mengetahui faktor pendukung strategi komunikasi interpersonal guru untuk membangun kepercayaan diri siswa kelas IX menghadapi USBN, 4). Untuk mengetahui faktor penghambat strategi komunikasi interpersonal guru dalam membangun kepercayaan diri siswa kelas IX untuk menghadapi USBN. Dengan keterbukaan, empati, sikap mendukung dan sikap positif. Diharapkan strategi komunikasi interpersonal ini bisa menumbuhkan kepercayaan diri siswa. Penelitian ini menggunakan metode penelitian kualitatif. Subjek penelitian yaitu: Guru IPS kelas IX, Siswa kelas IX diambil dari setiap kelas perwakilan 3 orang, dan Kepala Sekolah. Instumen pengumpulan data wawancara, Observasi dan dokumentasi. Analisis data menggunakan reduksi data, penyajian data, dan kesimpulan. Hasil Penelitian menyatakan bahwa Strategi Komunikasi Interpersonal dilakukan dengan keterbukaan, empati, dukungan dan rasa positif. Faktor pendukung dari strategi komunikasi interpersonal guru memberikan dukungan dalam bentuk motivasi, arahan dan melakukan pembelajaran yang aktif untuk siswa. Dalam faktor penghambat ini yaitu adalah keterbatasan media yang ada disekolah misalnya LCD-Proyektor, interaksi sosial, dan kultur atau bahasa yang digunakan banyak siswa yang tak paham. Sehingga komunikasi interpersonal guru dan siswa menjadi terhambat.
\end{abstract}

Kata kunci: Strategi Komunikasi Interpersonal Guru, Kepercayaan Diri Siswa, USBN 


\begin{abstract}
This research is motivated Many students who experienced a confidence crisis when following (USBN). Like the feeling of disbelief, insecure, fearful, restless and anxious that experienced by students so feel unable to yourself to do the USBN problem. It takes communication skills by teachers to build a sense of confidence in students through interpersonal communication. The purpose of this research are: (1). To know the confidence of class $I X$ students in the face of USBN, (2). To know the interpersonal communication strategy of teacher to build confidence of class IX students facing USBN, (3). To know the supporting factor of teacher interpersonal communication strategy to build confidence of class IX students facing USBN, (4). To know the inhibiting factor of teacher interpersonal communication strategy in building confidence of class IX students to face USBN. Confidence is one of the most important aspects of personality in human life. As for building confidence required a good communication strategy between teachers and students. For. By using the theory of human communication strategy that is, openness, empathy, supportive attitude and positive attitude. It is expected that this interpersonal communication strategy can foster students' selfconfidence. This study used qualitative research methods. Research subjects are: IPS Class IX Teachers, Class IX students are taken from each representative class 3 people MTsN, (junior high school) and Principal. Instument data collection interview, observation and documentation. Data analysis uses data reduction, data presentation, and conclusions. The result of research stated that Interpersonal Communication Strategy conducted by teachers at MTsN , (junior high school) 10 Majalengka to develop self-confidence of class IX students is done with openness, empathy, support and positive feeling. Supporting factors of interpersonal communication strategy to foster self-confidence of class IX students provide support in the form of motivation, direction and active learning for students. In this limiting factor is the limitations of existing media in schools such as LCD-Projector, social interaction, and culture or language used by many students who do not understand. So that the interpersonal communication of teachers and students become obstructed.
\end{abstract}

Keywords: Master's Interpersonal Communication Strategy, Student Self Confidence, USBN

\title{
A. PENDAHULUAN
}

1. Latar Belakang Masalah

Banyak siswa yang mengalami krisis kepercayaan diri saat mengikuti Ujian Akhir Sekolah Berstandar Nasional (USBN), hal ini disebabkan karena rasa tidak percaya diri, minder, takut, khawatir dan resah yang dialami oleh siswa. Sehinga hal tersebut akan berdampak pada menurunya kondisi tubuh, dan akhirnya daya konsentrasi siswa ketika mengikuti USBN akan terganggu 
dan melemah. Maka berbagai kemungkinan pun dapat terjadi, seperti kebingungan, guguo, resah, menurunnya konsentrasi ketika mengerjakan soal ujian. Peran guru di sekolah sangatlah penting dalam membimbing para siswanya. Berdasarkan Peraturan Pemerintah No. 29 tahun 1990 secara tegas mengemukakan, para guru pembimbing diwajibkan untuk membangun kompetensi dalam rangka upaya menemukan pribadi, mengenal lingkungan, dan merencanakan masa depan siswanya. Dengan menjalin hubungan baik antara siswa dengan guru ini akan mempengaruhi proses perkembangan siswa kearah yang lebih baik. sehingga proses penanaman kepercayaan diri dapat berjalan dengan lancar tanpa ada sekat-sekat yang memisahkan antara guru dengan siswanya.

Kepercayaan diri berawal dari sendiri dan dorongan dari orang lain. Hendaknya setiap individu/siswa menanamkan sikap percaya diri. Terlebih mereka akan menghadapi USBN. Setiap siswa harus memiliki kenyakinan kuat di dalam dirinya sendiri untuk melakukan tindakan-tindakannya.

Menurut Setiawan (2014:14) Percaya diri adalah kondisi mental atau psikologis seseorang, dimana individu dapat mengevaluasi keseluruhan dan dirinya sehingga member keyakinan kuat pada kemampuan dirinya untuk melakukan tindakan dalam mencapai berbagai tujuan didalam hidupnya.

Thantaway menjelaskan dalam kamus istilah bimbingan konseling (dalam Komunikasi Pendidikan 2013:87), percaya diri adalah kondisi mental atau psikologis diri seseorang yang memberi keyakinan kuat pada dirinya untuk berbuat atau melakukan sesuatu tindakan. Jika proses penanaman tersebut dilakukan jauh-jauh hari untuk menghadapi Ujian Akhir Sekolah Berstandar Nasional (USBN) maka akan terdapat kemungkinan siswa tidak akan mengalami kecemasaan, gugup, stres secara berlebihan. Sebaliknya, apabila proses penanaman tersebut dilakukan secara mendadak bahkan tidak ditanamkan sama sekali bisa dipastikan para siswa akan mengalami kecemasan dan stres yang berlebihan bahkan bisa mengalami depresi sehingga akan mengakibatkan kegugupan serta dapat menurunkan daya konsentrasi bagi para siswa. Jadi pada inti permasalahan ini adalah banyak siswa yang mengalami krisis kepercayaan diri saat akan menjalankan USBN, hal yang banyak dialami 
siswa ini seperti cemas, takut, grogi, dan merasa tidak mampu pada diri sendiri untuk mengerjakan soal USBN. Sehingga muncul rasa tidak percaya diri di dalam diri siswa. Untuk itu dibutuhkan kecakapan komunikasi yang dilakukan guru agar menumbuhkan rasa kepercayaan diri di dalam diri siswa melalui komunikasi interpersonal. Adapun unsur komunikasi interpersonal itu melalui teori komunikasi antarmanusia (Devito, Joseph, 2011:20). yang termuat di dalamnya yaitu: keterbukaan, empati, dukungan, dan rasa positif.

Berdasarkan permasalahan tersebut penulis merasa tertarik untuk meneliti tentang: "Strategi komunikasi interpersonal guru dalam membangun kepercayaan diri siswa kelas IX menghadapi USBN (Ujian Sekolah Berstandar Nasional) di MTs Negeri 10 Majalengka”.

2. Rumusan Masalah

Berdasarkan identifikasi masalah di atas, maka pertanyaan penelitian dalam penelitian ini adalah :

a. Bagaimana kepercayaan diri siswa kelas IX untuk menghadapi USBN di MTs Negeri 10 Majalengka?

b. Bagaimana Strategi komunikasi interpersonal guru untuk membangun kepercayaan diri siswa kelas IX menghadapi USBN di MTs Negeri 10 Majalengka?

c. Bagaimana faktor pendukung strategi komunikasi interpersonal guru untuk membangun kepercayaan diri siswa kelas IX menghadapi USBN di MTs Negeri 10 Majalengka?

d. Bagaimana faktor penghambat strategi komunikasi interpersonal guru dalam membangun kepercayaan diri siswa kelas IX untuk menghadapi USBN di MTs Negeri 10 Majalengka?

\section{Tujuan Penelitian}

Tujuan yang akan dicapai dalam penelitian ini yaitu sebagai berikut:

a. Untuk mengetahui kepercayaan diri siswa kelas IX untuk menghadapi USBN di MTs Negeri 10 Majalengka.

b. Untuk mengetahui strategi komunikasi interpersonal guru untuk membangun kepercayaan diri siswa kelas IX menghadapi USBN di MTs Negeri 10 Majalengka. 
c. Untuk mengetahui faktor pendukung strategi komunikasi interpersonal guru untuk membangun kepercayaan diri siswa kelas IX menghadapi USBN di MTs Negeri 10 Majalengka.

d. Untuk mengetahui faktor penghambat strategi komunikasi interpersonal guru dalam membangun kepercayaan diri siswa kelas IX untuk menghadapi USBN di MTs Negeri 10 Majalengka.

\section{B. KAJIAN TEORI}

1. Pengertian Komunikasi Interpersonal

Menurut Wibowo komunikasi merupakan aktifitas menyampaikan apa yang ada di pikiran, konsep yang kita miliki dan keinginan yang ingin kita sampaikan pada orang lain. Atau sebagai seni mempengaruhi orang lain untuk memperoleh yang kita inginkan. (B.S. Wibowo, 2002). Sehingga dari definisi diatas dapat disimpulkan bahwa tujuan komunikasi adalah untuk mendapatkan dampak (efek) kognisi yaitu berkenaan dengan pengetahuan, afeksi berkenaan dengan penyampaian perasaan atau pikiran dan konasi yang berkenaan perubahan sikap dan perilaku.

Komunikasi Interpersonal adalah komunikasi yang terjadi antara dua orang atau lebih, yang biasanya tidak diatur secara formal. Dalam komunikasi interpersonal, setiap partisipan menggunakan semua elemen dari proses komunikasi. Misalnya masing-masing pihak akan membicarakan latar belakang dan pengalaman masing-masing dalam percakapan tersebut. Pengertian komunikasi interpersonal sendiri adalah komunikasi antar orang-orang dengan cara bertatap muka, yang memungkinkan setiap pesertanya menangkap reaksi orang lain secara langsung, baik secara verbal maupun nonverbal (Mulyana, 2009: 81).Hardjana (dalam Suranto, 2011:3) mengatakan, komunikasi interpersonal atau antarpribadi adalah interaksi tatap muka antar dua orang atau beberapa orang, di mana pengirim dapat menyampaikan secara langsung dan penerima pesan dapat menerima dan menanggapi secara langsung. 


\section{Pengertian Kepercayaan Diri}

Menurut Angelis (Hakim 2002: 11) rasa percaya diri sebagai kenyakinan pada kemampuan diri sendiri yang mana percaya diri itu berawal dari tekad pada diri sendiri untuk melakukan segala sesuatu yang diinginkan dan dibutuhkan dalam hidup. Ditambahkan oleh Liendenfield (Hakim 2002: 11) rasa percaya diri lebih menekankan pada kepuasan yang dirasakan individu terhadap dirinya, dengan kata lain individu yang percaya diri adalah individu yang merasa puas pada dirinya sendiri.

Wijaya (Hakim 2002:11) mendefinisikan kepercayaan diri adalah kekuatan keyakinan mental seseorang atas kemampuan diri kondisi dan mempunyai pengaruh terhadap kondisi dan perkembangan kepribadian seseorang secara keseluruhan.

Menurut Iskarima (2009:22) unjuk diri pada anak dilakukan dengan memberikan kebebasan pada anak untuk mengekspresikan individualitasnya dan memfokuskan energi pada hobi yang menarik minat mereka, maka kepercayaan dirinya akan meningkat, dan juga motivasinya unuk melakukan hal yang baik di bidang lain.

2. Ujian Akhir Sekolah Berstandar Nasional (USBN)

Menurut Peraturan Dirjen Pendidikan Dasar dan Menengah Nomor: 08/D/HK/2017, tentang POS USBN pada Pendidikan Dasar dan Menengah Tahun Pelajaran 2016/2017, di bagian ketentuan umumnya disebutkan bahwa USBN adalah: kegiatan pengukuran capaian kompetensi siswa yang dilakukan sekolah untuk mata pelajaran tertentu dengan mengacu pada standar Kompetensi Lulusan untuk memperoleh pengakuan atas prestasi belajar.

3. Pengertian Strategi komunikasi

Pemahaman tentang suatu strategi merupakan suatu gagasan atau konsepsi, yang dimana gagasan atau konsepsi tersebut digunakan sebagai setandar dan batasan-batasan untuk melangkah. Kata strategi sendiri berasal dari bahasa yunani yaitu "stratos" yang artinya tentara dan kata “agein” yang berati pemimpin (Cangara, 2013:61). Tetapi disini yang dimaksud bukanlah strategi yang digunakan untuk menyusun kekuatan 
untuk perang atau untuk melawan musuh, tetapi strategi disini yang dimaksud adalah rencana, cara, taktik, atau siasat agar komunikasi yang disampaikan komunikator kepada pendengar dapat diterima dengan baik (Cangara, 2013:61).

Adapun menurut Anwar Arifin dalam buku "Strategi Komunikasi" (1984:10) menyatakan bahwa: Sesungguhnya suatu strategi adalah keseluruhan keputusan kondisional tentang tindakan yang akan dijalankan, guna mencapai tujuan. Dengan strategi komunikasi ini, berarti dapat ditempuh beberapa cara memakai komunikasi secara sadar untuk menciptakan perubahan pada diri khalayak dengan mudah dan cepat

4. Kajian Penelitian yang Relevan

Hasil penelitian yang dilakukan Heru Susanto (2015) Mengembangkan komunikasi interpersonal antara guru dengan siswa untuk meningkatkan efektivitas kegiatan belajar mengajar di SDN Tanjung.

a. Persamaan

Persamaan antara penelitian yang dilakukan oleh Heru Susanto dengan penelitian ini adalah mengkaji tentang komunikasi interpersonal guru.

b. Perbedaan

Perbedaannya yaitu jika penelitian yang dilakukan oleh Heru Susanto adalah meneliti tentang mengembangkan komunikasi interpersonal antara gur dan siswa tetapi penelitian yang akan peneliti lakukan yaitu mengkaji tentang strategi komunikasi interpersonal guru dalam membangun kepercayaan diri siswa.

\section{METODE PENELITIAN}

1. Jenis Penelitian

Penelitian ini menggunakan metode penelitian kualitatif sebagai pendekatan untuk mendapatkan pemahaman dari fenomena-fenomena dan kasus yang dipilih peneliti. Jenis penelitian ini adalah penelitian kualitatif deskriptif dengan pendekatan induktif. Penelitian kualitatif tidak mengutamakan besarnya populasi atau informan, bahkan populasi dan informan yang diambil sangat terbatas, karena sudah terfokuskan dengan 
masalah yang sudah ditentukan oleh peneliti. Jika data sudah mendalam dan cukup menjelaskan fenomena yang diteliti maka tidak perlu mencari informan lain. Menurut Bungin (2007: 68) penelitian deskriptif kualitatif bertujuan untuk menggambarkan, meringkas berbagai kondisi, fenomena, dan realitas sosial yang ada di lingkungan pendidikan yang menjadi objek penelitian.

2. Lokasi dan Waktu Penelitian

Penelitian dilakukan di MTs Negeri 10 Majalengka. Adapun waktu pelaksanaan penelitian dari bulan Januari - Maret 2018.

3. Sumber Data

Sumber data yang didapat dari sebagai berikut :

a. Data yang diperoleh secara langsung dari objek yang diteliti. Data ini dapat berupa hasil teks wawancara dan diperoleh melalui wawancara dengan informan yang sedang dijadikan sampel dalam penelitiannya.

b. Data yang diperoleh dari observasi berupa melihat lokasi sekolah lalu mengamati komunikasi interpersonal antara guru dengan siswa.

c. Dokumentasi berupa foto-foto yang peneliti hasilkan sendiri dengan kamera digital, catatan hasil wawancara yang diperoleh peneliti saat melakukan wawancara dengan subjek dan informan penelitian serta datadata lain yang dijadikan bahan tambahan untuk mendapatkan data objek penelitian.

4. Subyek Penelitian

Subyek penelitian terfokus pada Guru IPS, Siswakelas IX, dan Kepala Sekolah.

5. Teknik dan Instrumen Pengumpulan Data

a. Wawancara

Responden atau informan wawancara dalam penelitian ini akan dilakukan dengan Guru IPS, Siswa kelas IX, dan Kepala Sekolah, di MTs Negeri 10 Majalengka.

b. Observasi

Observasi yang dilakukan dalam hal ini, peneliti berkedudukan sebagai participant observer, yakni peneliti turut aktif pada waktu penelitian. 


\section{c. Dokumentasi}

Metode dokumentasi ini dimaksudkan untuk memperoleh data berdasarkan sumber data yang ada di Sekolah MTs Negeri 10 Majalengka.

6. Teknik Analisis Data

a. Pengumpulan data

Peneliti mencatat semua data secara objektif dan apa adanya sesuai dengan hasil observasi dan wawancara di lapangan.

b. Reduksi Data

Mereduksi data berarti merangkum, memilih hal-hal yang pokok, memfokuskan pada hal-hal yang penting dicari tema dan polanya dan membuang yang tidak perlu.

c. Display Data / Penyajian Data

Penyajian data berbentuk sekumpulan informasi yang tersusun sehingga dapat ditarik suatu kesimpulan. Penyajian data dilaksanakan agar sajian data tidak menyimpang dari pokok permasalahan.

d. Penarikan kesimpulan

Penarikan kesimpulan atau verifikasi adalah usaha untuk mencari atau memahami makna, keteraturan, pola-pola, penjelasan, alur sebab akibat atau proposisi. Verifikasi penulis lakukan setelah penyajian data selesai, dan ditarik kesimpulanya berdasarkan hasil penelitian lapangan yang telah dianalisis dengan teori.

7. Keabsahan Data

Menurut Moleong (2009: 321) Keabsahan data merupakan konsep penting dalam sebuah penelitian yang validitas dan realibilitasnya harus disesuaikan dengan tuntuntan pengetahuan.

\section{HASIL PENELITIAN DAN PEMBAHASAN}

Penelitian ini dilakukan berkaitan dengan strategi komunikasi interpersonal guru dalam membangun kepercayaan diri siswa kelas IX di kelas IX MTs Negeri 10 Majalengka.Adapun kepercayaan diri siswa kelas IX yang akan menghadapi USBN banyak dari mereka yang merasa belum percaya diri 
saat akan melaksanakan USBN. Seperti cemas, khawatir dan takut saat akan menghadapi USBN. Adapun rasa tidak percaya diri itu muncul bukan karena tidak bisa mengerjakan soal, akan tetapi tidak percaya disini yaitu takut, resah tidak memiliki kesiapan mental dan fisik dalam menghadapi USBN. Adapun kecemasan yang dirasakan siswa, mereka merasakan rendah diri, ketakutan, kegelisahan. Untuk itulah perlu strategi komunikasi interpersonal guru dalam membangun kepercayaan diri siswa seperti keterbukaan, empati, sikap mendukung, dan sikap positif.

Karena dengan percaya diri memberikan kebebasan kepada siswa, jika siswa percaya diri maka siswa akan dengan leluasa dalam melakukan sesuatu, mengapa demikian, karena siswa yakin bahwa bisa melakukannya dengan baik. Lalu kejujuran bisa membebaskan siswa. Tidak ada topeng yang dipakai, jangan khawatir dengan apa yang orang lain katakana. Jujurlah pada diri sendiri dan orang lain khususnya kepada guru. Dan para siswa kelas IX harus yakin kalau siswa kelas IX bisa melakukan/melaksanakan USBN. Selain itu juga dengan memiliki rasa percaya diri tidak akan memiliki ketakutan. Ketika para siswa benar-benar menerima, menyadari kelebihan dan kelemahan diri sendiri, siswa tidak akan mencoba untuk menyembunyikannya tetapi siswa akan mencoba yang terbaik dari diri para siswa. Tidak perlu takut dengan kegagalan atau kritikan orang lain. Dengan percaya diri para siswa tidak akan merasakan ketakutan ketika siswa tidak yakin dalam melakukan sesuatu, ataupun ketika dikritik tentang kelemahan siswa.

Demi terlaksananya strategi komunikasi interpersonal yang dilakukan antara guru dengan siswa perlu adanya faktor pendukung untuk menumbuhkan kepercayaan diri siswa kelas IX yaitu dengan dukungan. Seperti guru memberikan dukungan dalam bentuk motivasi, arahan dan melakukan pembelajaran yang aktif untuk siswa. Guru mengajak siswa aktif dalam pembelajaran, dengan memberikan video dalam kegiatan pembelajaran agar anak mendapatkan stimulus memberikan pendapat dalam proses pembelajaran sehingga timbul ada rasa percaya diri dalam diri siswa. Namun dalam hal ini tidak berjalan dengan lancar, ada faktor penghambat komunikasi interpersonal guru untuk menumbuhkan kepercayaan diri siswa kelas IX menghadapi USBN. 
Adapun faktor penghambatnya yaitu dikarenakan keterbatasan media yang ada disekolah seperti LCD-Proyektor, interaksi sosial, dan kultur atau bahasa yang digunakan banyak siswa yang tak paham. Sehingga komunikasi interpersonal guru dan siswa menjadi terhambat. Untuk itu sekolah hendaknya memberikan fasilitas yang lebih memadai agar komunikasi yang dilakukan atara guru bisa tersampaikan sesuai dengan harapan siswa.

Dinamika psikis adalah energi kejiwaan yang mengerakkan, yang penuh dinamika, yang akan membawa dan menuju sukses dalam menghadapi ujian USBN. Energi adalah kemampuan untuk bertindak. Energi merupakan ketetapan hati yang tidak tampak yang dimiliki oleh setiap orang untuk melakukan sesuatu yang menyenangkan hati mereka. Dalam diri siswa terdapat dua macam energi yaitu energi fisik dan energi psikis. Energi psikis jauh lebih penting dari energy fisik, karena dari alam bawah sadar yang dapat menimba banyak daya dan kekuatan disaat dibutuhkan. Ditinjau dari segi energi, siswa yang kondisi psikologisnya mengalami kecemasan atau ketakutan, siswa tersebut sedang mengalami kehidupan keredupan energy psikis dirinya, ibarat lampu yang kehilangan pancaran sinarnya, padahal sinar itu mengandung makna bagi dirinya sendiri dan bermanfaat bagi lingkungan sekitarnya.

Guru sebagai Kordinator dan Inovator. Untuk mengomunikasikan pembelajaran secara efektif kepada siswa, guru dapat berperan sebagai koordinator dan inovator. Komunikasi pembelajaran tidak hanya membutuhkan kemampuan verbal dalam berkomunikasi, tapi juga kemampuan mendesain sumber belajar dan media pembelajarannya. guru sering kurang menyadari begitu banyaknya media yang bisa dijadikan alat bantu pembelajaran, misalnya, film, video-audio, majalah, dan internet. Bagi guru yang kreatif dan inovatif, apa saja yang ada di kelas bisa menjadi alat bantu pembelajaran. Di era digital seperti sekarang, ada banyak hal yang bisa dijadikan sebagai sumber belajar dan alat bantu pembelajaran seperti e-mail, milis, jejaring sosial, dan blog. Keberadaan media dan sumber pembelajaran tersebut tersebut memudahkan guru mengomunikasikan pembelajaran. Satu hal yang perlu diingat guru dalam menggunakan sumber belajar secara efektif adalah 
penguasaan dan pemahaman tas media tersebut sehingga penggunaannya di kelas dapat meningkatkan kualitas pembelajaran.

Berarti dalam hal ini siswa dan siswi di MTs Negeri 10 Majalengka pada awalnya merasa kurang percaya diri untuk menghadapi USBN. Akan tetapi dengan pembelajaran yang aktif yang selalu diberikan oleh guru serta motivasi, arahan, latihan dalam mengerjakan soal USBN dan dukungan, siswa bisa mendapatkan kepercayaan diri untuk menghadapi Ujian Sekolah Berstandar Nasional dibuktikan dengan kesiapan untuk melaksanakan USBN tersebut dan juga strategi komunikasi interpersonal guru memberikan kontribusi untuk siswa menumbuhkan kepercayaan diri. Danguru harus terus meningkatkan kinerja dan profesionalisme yang baik.

Penguasaan strategi komunikasi merupakan kemampuan dasar dan vital yang harus dimiliki seorang pendidik guna mendukung ketercapaian kompetensi/subkompetensi dalam pembelajaran. Melalui penerapan strategi komunikasi yang efektif diharapkan seorang guru mampu mengorganisasi dan mengkoordinasi kemauan siswa dapat belajar untuk menyelesaikan tujuan pendidikannya. Sehingga siswa dapat belajar dalam suasana yang menyenangkan dan beraktivitas tinggi baik secara mental, fisik, sosial, maupun emosinya. Hal tersebut baru bisa dicapai jika didukung oleh kepribadian guru yang matang dan kesadaran untuk mengelola proses pembelajaran dengan menaati dan menetapkan asas-asas didaktik dalam setiap momentum yang tepat khususnya di dalam ruangan kelas.

Melalui penerapan strategi komunikasi yang efektif ini pulalah seorang guru diharapkan dapat membangun suasana pembelajaran yang produkti, kreatif, dan inovatif, sehingga tidak hanya kesuksesan saja dalam sebuah proses pembelajaran melainkan tertanam sikap percaya diri yang harus dimiliki oleh para siswa khususnya siswa kelas IX.

\section{E. KESIMPULAN DAN SARAN}

1. Kesimpulan

Berdasarkan hasil penelitian yang peneliti lakukan, maka dapat disimpulkan data dan uraian sebagai berikut: 
a. Kepercayaan diri siswa kelas IX untuk mengahadapi USBN kurang maksimal. Mereka merasa cemas, gelisah, khawatir akan soal ujian yang akan di USBN kan. Ada beberapa diantara siswa kurang aktif saat melaksanakan proses pembelajaran. Dari sinilah bisa dilihat bahwa rasa percaya diri yang ada dalam diri siswa menurut informan belum sesuai yang diharapkan oleh guru atau kurang percaya diri.

b. Strategi Komunikasi Interpersonal yang dilakukan guru di MTs Negeri 10 Majalengka untuk menumbuhkan kepercayaan diri siswa kelas IX dilakukan dengan menggunakan teori strategi komunikasi antarmanusia yaitu, keterbukaan, empati, sikap mendukung dan sikap positif.

c. Faktor pendukung dari Strategi komunikasi interpersonal untuk menumbuhkan kepercayaan diri siswa kelas IX menghadapi USBN yaitu guru memberikan dukungan dalam bentuk motivasi, arahan dan melakukan pembelajaran yang aktif untuk siswa. Mengajak siswa aktif dalam pembelajaran, dengan memberikan video dalam kegiatan pembelajaran agar anak dapat terangsang memberikan pendapat dalam proses pembelajaran sehingga timbul ada rasa percaya diri dalam diri siswa.

d. Faktor penghambat yaitu adalah dikarenakan oleh keterbatasan media yang ada disekolah misalnya LCD-Proyektor, interaksi sosial, dan kultur atau bahasa yang digunakan banyak siswa yang tak paham. Sehingga komunikasi interpersonal guru dan siswa menjadi terhambat.

2. Saran

a. Siswa diharapkan bisa lebih baik menjalin komunikasi interpersonal dengan guru agar bisa mengatasi krisis kepercayaan diri. Dengan berkomunikasi dengan guru setidaknya beban yang dirasakan oleh siswa bisa terpecahkan atau berkurang karena dengan berkomunikasi akan mendapatkan solusi dan motivasi.

b. Dalam proses kegiatan belajar mengajar, seorang guru membutuhkan strategi komunikasi interpersonal dengan siswa, tidak hanya sebatas menyampaikan teoritis saja tapi harus dibarengi dengan praktek agar 
siswa semangat dalam melalui pembelajaran. Guru juga harus jangan bosen selalu berkomunikasi dengan siswa-siswi agar hubungan terjalin dengan baik, baik dalam komunikasi memotivasi atau kegiatan pembelajaran.

c. Dukungan berupa Fasilitas yang menunjang proses pembelajaran adalah hal yang harus diutamakan agar siswa mampu belajar dengan baik dan nyaman. Selain itu pihak sekolah juga diharapkan agar selalu mendukung kinerja guru, dalam komunikasi interpersonal antara guru dengan siswa, agar para siswa bisa menumbuhkan kepercayaan diri untuk menghadapi USBN.

\section{DAFTAR PUSTAKA}

Ahmad. Susanto. (2011). Psikologi Perkembangan Anak Usia Dini: Pengantar Dalam Berbagai Aspeknya. Jakarta: Kencana.

Agoes. Dariyo. (2011). Psikologi Perkembangan Anak Tiga Tahun Pertama. Bandung: Refika Aditama.

Anwar. Arifin. (1984). Strategi Komunikasi. Bandung: Amrico.

Cangara, Hafied. (2013). Pengantar Ilmu Komunikasi. Jakarta: Raja Grafindo Persada.

Hakim. (2002). Mengatasi Rasa Tidak Percaya Diri. Jakarta: Puspa Swara.

Iskarima. Ratih. (2009). Super Confident Child: Tips Agar Anak Pemberani dan Percaya Diri. Yogyakarta: Impremium.

J. Moleong, Lexy.(2009). Metodologi Penelitian Kualitatif. Bandung: Remaja Rosdakarya.

Mulyana, Deddy. (2009). Ilmu Komunikasi Suatu Pengantar. Bandung: Remaja Rosdakarya.

Wibowo. B.S. (2002). Hubungan Percaya Diri dengan Motivasi. Jakarta: Kencana Prenada Media Group.

http://elib.Unikom.ac.id.penelitianrelevan.ac.id. Penelitian yang dilakukan Heru Susanto (2015). Mengembangkan komunikasi interpersonal antara guru dengan siswa untuk meningkatkan efektivitas kegiatan belajar-mengajar di SDN Tanjung. Diakses pada hari Selasa 14/11/2017 Pukul:11:32 AM. 